\title{
Controlled atmosphere GMAW welding of transportation vehicles and production machines parts made from $30 \mathrm{MnB} 5$ steel
}

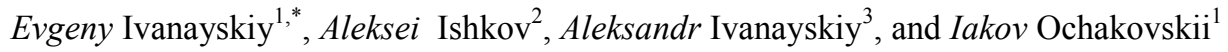 \\ ${ }^{1}$ Polzunov Altai State Technical University, 656049 Barnaul, Russia \\ ${ }^{2}$ Altai State Agricultural University, 656049 Barnaul, Russia \\ 3“Emissiia” LLC, 656067 Barnaul, Russia
}

\begin{abstract}
The paper studies the influence of shielding gas on the composition and the structure of weld joint metal of 30MnB5 steel applied in essential parts of automobiles and tractors. The welding was performed in inert, oxidizing and reducing atmospheres. It was established that TIG welding with argon used as shielding gas did not provide the required mechanical properties when using conventional welding materials. Carbon dioxide during MAG welding caused partial burning of alloying elements. Carbon monoxide used as shielding gas was proved to form reducing atmosphere enabling to obtain chemical composition close to the base metal composition. Metallographic examinations were carried out. The obtained results provided full-strength weld, as well as the required reliability and durability of welded components and joints.
\end{abstract}

\section{Introduction}

Boric steels are getting wider use in manufacture of various types of wheeled and caterpillar vehicles for production of wear resistant cover plates, knives, caterpillar tracks, liner and screen plates, crushing units and other details. Composition and properties of these steels are defined by the requirements of EN 10083, along with the national standards elaborated on their basis. Steels are characterized by low hardness after rolling, they are easy to mold and cut, thus enabling manufacturing complex parts and products. Quenching and tempering provide high strength combined with good notch toughness, high wear resistance and resistance to mechanical loading. Along with that, welding of these steels not only changes the chemical composition of the weld joint but also softens the heat-affecting zone subjected to thermal cycle.

A number of research works were devoted to different combinations of welding materials used for Boric microalloyed steels welding. The authors of [1] suggest using conventional welding wire Sv-08G2S (Russian grade) with addition of $0.005 \%$ Boric suitable for welding in carbon dioxide $\left(\mathrm{CO}_{2}\right)$. Production technology of these wires was elaborated, however data on the composition and properties of the weld joint was not provided. Other research [2] indicates positive influence of Boric content $>0.002 \%$ on the

\footnotetext{
'Corresponding author: 609185@mail.ru
} 
steel microstructure. L.N. The research [3] was focused on the properties of weld joints made from low-carbon steel 10G2FB (Russian grade) by flux-cored wire with Boric. The Boric content in the weld joint amounted to $0.0025 \% \ldots 0.0065 \%$. Orlov et al. [4] determined that Boric microalloying of weld joint through flux was insufficiently reliable due to low metallurgic activity of Boric oxide in the welding flux. Authors suggested using special flux-cored wires providing Boric content in the weld joint metal of up to $0.0065 \%$. Larger Boric content indicated crack formation in the weld joint.

All welding methods mentioned above, as well as manual arc welding use $\mathrm{CO}_{2}$ as shielding gas. It is known [5] that high temperature causes dissociation of carbon dioxide into carbon, carbon monoxide and oxygen which are dissolved in a fluxed molten weld pool or recombined in colder areas of the arc into carbon dioxide. The generated free oxygen reacts with alloying elements forming oxides [6]. Studies [7, 8] demonstrate that active oxidation of carbon dioxide and alloying elements from drops takes place during melting and arc transfer of molten metal. The oxidation velocity increases along with the increase in oxidation capacity of the environment [7]. The loss of alloying elements occurs both due to oxidation and due to evaporation from the surface of the drop. The ratio between the content of evaporating and oxidizing element is determined by the content of oxygen in the gas phase and the welding mode [8].

In the view of the above mentioned, the objective was defined as selection of shielding gas which does not cause oxidation of alloying elements. Currently [9] for these purposes either inert gases ( $\mathrm{Ar}$ and $\mathrm{He}$ ), or reducing atmospheres containing inert gases and hydrogen are used.

The purpose of this study is to investigate various methods of electric-arc welding of parts of transportation vehicles and production machines made from Boric microalloyed steels. The research novelty consists in application of reducing shielding atmosphere based on carbon monoxide $(\mathrm{CO})$ to prevent burning of alloying elements.

\section{Materials and methods}

The material used in the research is $30 \mathrm{MnB} 5$ steel, which is a replacement of $65 \mathrm{G}$ steel. Chemical composition of the base metal of weld joints made by various welding methods can be found in Table 1.

Steel was welded using Sv-08G2S welding wire. The obtained specimens were further water quenched from the temperature $880 \ldots 900^{\circ} \mathrm{C}$. Microstructure, hardness and microhardness of various parts of weld joints were investigated.

In order to study the behavior of alloying elements during welding chemical analysis was conducted using DFS-500 optical emission spectrometer. Theoretical studies of possible chemical reactions ongoing at temperatures higher than the melting temperature were conducted based on the methods described in [10], and the reference data from the website [11].

\section{Experiment and results}

According to the data of manufacturer [12] conventional welding technologies with lowhydrogen welding materials can be applied for $30 \mathrm{MnB} 5$ steel. Initially for manufacturing parts of transportation vehicles and production machines MAG (Metal Active Gas) welding was used which is the most common method of industrial welding. However, substantial drop in operational life of the equipment was noted. It was found that after quenching hardness of the base material was $46 \ldots 48 \mathrm{HRC}$ and hardness of the weld joint metal was $32 . .34$ HRC. Chemical analysis (Table 1) showed that in the weld joint decrease in the 
content of carbon (C), manganese (Mn) and Boric (B) took place, and some increase in the content of silicium $(\mathrm{Si})$, apparently due to its transition from the welding wire.

Table 1. Results of chemical analysis (on the side of weld bed which is melted the last).

\begin{tabular}{|c|c|c|c|c|c|c|c|c|}
\hline \multicolumn{7}{|c|}{ Chemical composition, \% wt } & \multirow{2}{*}{ Notes } \\
\hline 0.348 & 0.225 & 1.259 & 0.015 & 0.044 & 0.003 & 0.0069 & 0.0085 & $\begin{array}{c}30 \text { MnB5 Steel base } \\
\text { metal }\end{array}$ \\
\hline 0.120 & 0.617 & 1.109 & $\begin{array}{c}\text { Trace } \\
\text { levels }\end{array}$ & 0.104 & $\begin{array}{c}\text { Trace } \\
\text { levels }\end{array}$ & 0.0058 & 0.0079 & $\begin{array}{c}\text { Welding in } \mathrm{CO}_{2} \\
\text { atmosphere }\end{array}$ \\
\hline 0.072 & 0.456 & 1.093 & $\begin{array}{c}\text { Trace } \\
\text { levels }\end{array}$ & 0.061 & $\begin{array}{c}\text { Trace } \\
\text { levels }\end{array}$ & 0.0059 & 0.0071 & $\begin{array}{c}\text { Welding in Ar } \\
\text { atmosphere }\end{array}$ \\
\hline 0.178 & 0.692 & 1.268 & 0.010 & 0.131 & 0.002 & 0.0097 & 0.0072 & $\begin{array}{c}\text { Welding in CO } \\
\text { atmosphere }\end{array}$ \\
\hline
\end{tabular}

TIG welding was applied to reduce burning of the alloying elements. Argon (Ar) was used as shielding gas. Chemical composition of weld metal can be also seen in Table 1. It should be noted that in all cases chemical composition was determined from the side of weld joint reinforcement.

Generally, when applying manual argon-arc welding a significant decrease in the content of almost all alloying elements was observed (Table 1). The hardness of the joint metal after quenching was $<20 \mathrm{HRC}$ (Fig. 1). Microhardness of the quenched specimens was measured along the section of the weld joint, and metallographic analysis of the metal structure was conducted. It was established that the argon-arc welded specimens had sufficient structural inhomogeneity. The core zone had typical martensite structure with hardness value of $41 \ldots 47 \mathrm{HRC}$. In the mid-zone of the weld joint one could observe the structure of upper bainite with release of accicular ferrite. Therefore, the decrease in the value of material hardness up to $30 \ldots 20 \mathrm{HRC}$ occurred depending on the place of measurement. This can be explained by low mixing coefficient of the base and electrode metal where there were no Boric and the carbon content did not exceed $0.11 \%$ [13].

Upper zones of the weld joint had hardness $<20 \mathrm{HRC}$. The metal coincided with the unalloyed low-carbon steel in its composition and had Widmanstatten structure containing pearlite grains with accicular precipitates of ferrite and rounded grains of ferrite. Separate zones with the structure of upper bainite were observed. The velocity of cooling was insufficient for the formation of martensite structure. In these conditions the absence of active chemical reactions between the molten weld pool and inert gas shielding atmosphere is suggested.

Thus, it was found that application of MIG/MAG technologies and TIG welding does not provide the required properties for parts of transportation vehicles and production machines.

It is known that heating of welding arc causes dissociation of carbon dioxide with release of atomic oxygen, for that reason these atmospheres are considered to be oxidizing $(1,2)$.

$$
\begin{aligned}
& 2 \mathrm{CO}_{2} \leftrightarrow 2 \mathrm{CO}+\mathrm{O}_{2} \\
& 2 \mathrm{CO} \leftrightarrow 2 \mathrm{C}+\mathrm{O}_{2}
\end{aligned}
$$

Along with that, $\mathrm{CO}$ possesses explicit reducing properties and is widely used in metallurgical industry for metal reduction from oxides. The use of $\mathrm{CO}$ during welding was 
restrained by its harmful biological effect. The authors in [14] propose pre-heating of monoxide at the temperature higher than the flashpoint resulting into its burning in the air atmosphere with the formation of harmless $\mathrm{CO}_{2}(2)$.

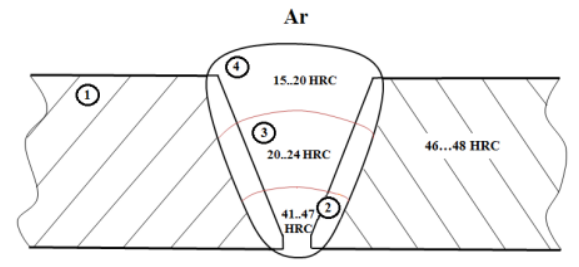

a)

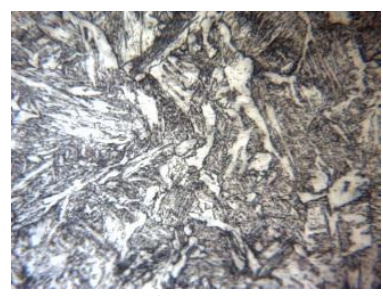

c) $\times 500$

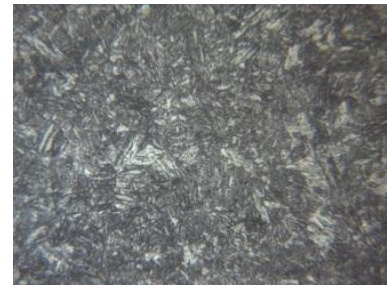

b) $\times 500$

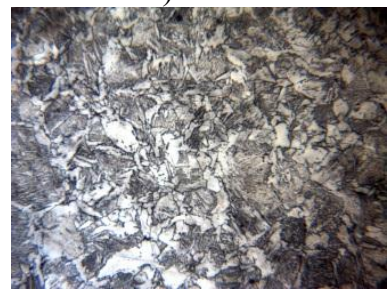

d) $\times 500$

Fig. 1. The scheme of weld joint of $30 \mathrm{MnB} 5$ steel welded in $\mathrm{CO}_{2}$ atmosphere (a) and microstructure of the zone 2 (b), 3 (c), 4 (d).

Gibbs thermodynamic potential calculations $\Delta \mathrm{G}$ demonstrated that such alloying elements as $\mathrm{Cu}, \mathrm{Ni}, \mathrm{Co}, \mathrm{Mo}, \mathrm{W}, \mathrm{Cr}, \mathrm{Mn}, \mathrm{Si}, \mathrm{B}$, within the temperature range $1500 \ldots 3500^{\circ} \mathrm{K}$ do not react with $\mathrm{CO}$. Alternately, the oxide reduction reactions of the mentioned elements will take place except for Si and B.

Welding of specimens from $30 \mathrm{MnB} 5$ steel was conducted in the reducing atmosphere on conventional equipment for mechanized welding in active gases atmosphere. $\mathrm{CO}$ was used instead of $\mathrm{CO}_{2}$. The improved burner provided heating of the fed carbon monoxide up to the temperature of $870 \ldots 900^{\circ} \mathrm{K}$. As it can be seen from Table 1 the content of $\mathrm{C}, \mathrm{Si}, \mathrm{Mn}$, $\mathrm{Cr}$ and $\mathrm{Cu}$ in the joint metal increased. This proves that these elements are not burned during welding in $\mathrm{CO}$ atmosphere. Therefore, the hardness of the joint metal also increased up to $32 \ldots 43$ HRC depending on the zone of weld joint (Fig. 2).

The weld joint after quenching had martensite microstructure in the lower zone, ferritemartensite in the middle part and bainite in the upper part. Quenching structures were formed in spite of the decrease in carbon content due to mixing of the base and electrode metals.

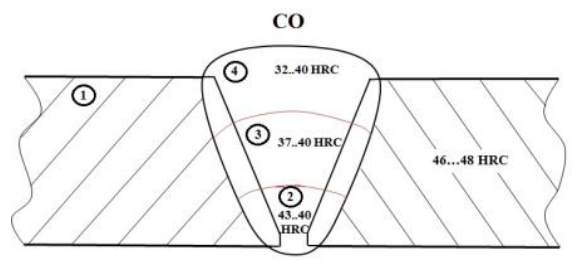

a)

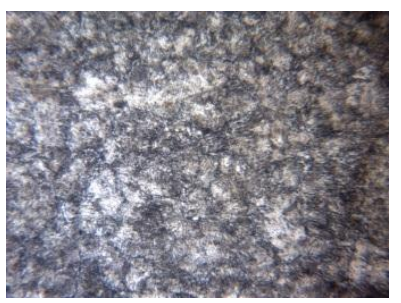

b) $\times 500$ 


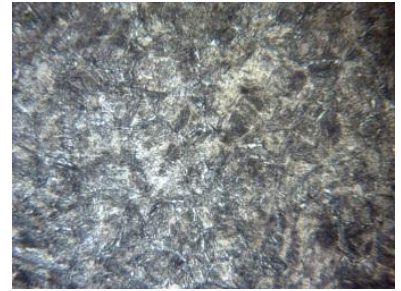

c) $\times 500$

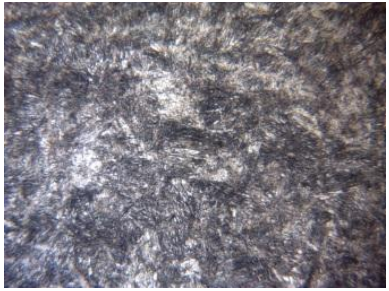

d) $\times 500$

Fig. 2. Scheme of the weld joint from $30 \mathrm{MnB} 5$ steel welded in $\mathrm{CO}$ atmosphere (a) and microstructure of the zone 2 (b), 3 (c), 4 (d).

Use of carbon monoxide shielding atmospheres during arc welding enables to broaden significantly the application area of alloyed wires during mechanized welding. The recommended gas atmosphere provides stable arcing and good formation of weld joint.

\section{Conclusion}

It was established that the parts of transportation vehicles and production machines made from Boric microalloyed steels when using the most common welding methods have zones of lower hardness which reduce their operational life. Using carbon monoxide as shielding gas prevents burning of alloying elements and enables to provide the required mechanical properties. Application of reducing atmospheres during mechanized welding allows broadening the application area of alloyed welding wires.

\section{References}

1. A.M. Nesterenko, A.B. Sychkov, V.I. Sukhomlin, Vestnik of Nosov Magnitogorsk State Technical University, No. 3, 30-32 (2012) (in Russian).

2. V.V. Parusov, A.B. Sychkov, I.V. Derevyanchenko, M.A. Zhigarev, Vestnik of Nosov Magnitogorsk State Technical University, No. 1(9), 15-17 (2005) (in Russian).

3. L.I. Faynberg, A.A. Rybakov, A.N. Alimov, R. Rozert, Avtomaticheskaya svarka [Automatic welding], 5, 20-25 (2007) (in Russian).

4. L.N. Orlov, M.G. Sharapov, V.L. Volynets, Sudostroenie [Ship construction], 5, 5457 (2010) (in Russian).

5. Lincoln Electric, Gas Metal Arc Welding. Product and Procedure Selection, available at:

http://www.lincolnelectric.com/assets/global/Products/Consumable MIGGMAWWire s-SuperArc-SuperArcL-56/c4200.pdf.

6. S. Noland, Select the right argon/ $/ \mathrm{CO}_{2}$ blend for your weld requirements. Practical welding today, 9/10, (2015).

7. P.A. Norin, N.I. Malyshev, S.V. Rushchits, Svarochnoe proizvodstvo [Welding production], 7, 4-6, (1980) (in Russian).

8. P.A. Norin, N.I. Malyshev, Svarochnoe proizvodstvo [Welding production], 2, 21-23 (1982) (in Russian).

9. W. Lucas, Shielding gases for arc welding and cutting, available at: https://www.twiglobal.com/technical-knowledge/published-papers/shielding-gases-for-arc-weldingand-cutting-may-2001. 
10. A.V. Ishkov, V.V. Ivanayskiy, N.T. Krivochurov, V.F. Aulov, D.V. Koval, A.V. Sokolov, V.A. Novozhenov, A.V. Novozhenov, Izvestiya of Altai State University, 3 (83), 199-203 (2014) (in Russian).

11. www.sciencebysimulation.com, Chemical reaction modeling and simulation app, available at: https://www.sciencebysimulation.com/chemreax/Analyzer.aspx.

12. METINVEST, Gorjachekatanyj tolstolistovoj prokat iz borsoderzhashhej stali marki $30 \mathrm{MnB} 5$ dlja zakalki i otpuska [Hot rolled thick-sheeted plate from boron steel of grade $30 \mathrm{MnB} 5$ for hardening and tempering], available at: https://sales.metinvestholding.com/upload/sales/technical_brochures/16/30MnB5_RU. pdf (in Russian).

13. GOST 2246-70. Welding steel wire. Specifications (Moscow, 1993) (in Russian).

14. E. Ivanayskij, A. Ivanayskiy, RU Patent 2570609 (2015) (in Russian). 